Georgia State University

ScholarWorks @ Georgia State University

$2-1-2008$

\title{
Global Reform of Personal Income Taxation, 1981-2005: Evidence from 189 Countries
}

Klara Sabirianova Peter

Georgia State University, kpeter@unc.edu

Steve Buttrick

Georgia State university

Denvil Duncan

Georgia State University

Follow this and additional works at: https://scholarworks.gsu.edu/uwrg_workingpapers

\section{Recommended Citation}

Peter, Klara Sabirianova; Buttrick, Steve; and Duncan, Denvil, "Global Reform of Personal Income Taxation, 1981-2005: Evidence from 189 Countries" (2008). UWRG Working Papers. 11.

https://scholarworks.gsu.edu/uwrg_workingpapers/11

This Article is brought to you for free and open access by the Usery Workplace Research Group at ScholarWorks @ Georgia State University. It has been accepted for inclusion in UWRG Working Papers by an authorized administrator of ScholarWorks @ Georgia State University. For more information, please contact scholarworks@gsu.edu. 
Andrew Young School of Policy Studies Research Paper Series

Working Paper 08-8

February 2008

Department of Economics

International Studies Program

\title{
Global Reform of Personal Income Taxation, 1981-2005: Evidence from 189 Countries
}

\author{
Klara Peter Sabirianova \\ Georgia State University
}

Steve Buttrick Georgia State University

Denvil Duncan Georgia State University

This paper can be downloaded at:

http://aysps.gsu.edu/publications/2008/index.htm

The Social Science Research Network Electronic Paper Collection: http://ssrn.com/abstract=1091534 


\title{
Global Reform of Personal Income Taxation, 1981-2005: Evidence from 189 Countries
}

\author{
Klara Sabirianova Peter \\ Georgia State University \\ IZA Bonn
}

\author{
Steve Buttrick
Georgia State University \\ Steve Buttrick
Georgia State University
}

\author{
Denvil Duncan \\ Georgia State University
}

February 1, 2008

\begin{abstract}
In this paper we use a panel of 189 countries to describe the salient trends that have emerged in national personal income tax systems spanning the twenty five year period from 1981 to 2005. Using complete national income tax schedules, we calculate actual average and marginal tax rates at different income levels as well as time-varying measures of structural progressivity and complexity of national tax systems. Overall, our analysis shows a significant transition from complex, graduated tax schedules that featured multiple tax brackets and stair stepped tax rates to simpler, flatter tax schedules distinguished by fewer tax brackets and lower rates. The emerging trend toward flat tax schedules is also highlighted. We show that frequent alterations of tax structures have diminished the overall progressivity and complexity of national tax systems; however, the degree of this change varies considerably by countries.
\end{abstract}

\section{Acknowledgement}

We are thankful to Danielle Steele and Jessica Van Parys for their assistance with data entry.

Keywords: personal income tax, tax complexity, progressivity, flat tax, global trends.

JEL Classification: C8, E62, H2, H87, N10, O1. 


\section{Introduction}

Economic development policies are often assessed on the grounds of achieving equity and efficiency. It is also commonly asserted that in most cases there is likely to be a tradeoff between these two objectives. The equity-efficiency tradeoff is particularly apparent with respect to progressive income taxation that is designed to promote greater equity but may also reduce individuals' incentives to work, thus creating inefficiencies. To a certain degree, the historical evolution of progressive income taxation might be indicative of the efficiency cost of equity or the equity cost of efficiency at different stages of economic development. It is in this light that we seek to examine the global trends in progressive income taxation over the last 25 years from 1981 to 2005.

About one hundred years ago, Seligman (1908) observes that "the tendency toward progressive taxation is almost everywhere on the increase”. However, the income tax progressivity at the beginning of the $20^{\text {th }}$ century was rather moderate, by contemporary standards. The top personal income tax (PIT) rate in 15 surveyed countries hardly exceeded 10\%. "The highest point known to history as actually enforced is thirty-seven and a half percent”, which lasted only a year in Holland in 1796. Referring to this case, Seligman remarks "the progression was so severe as to become a confiscation”.

By 1981, the 37.5\% top PIT rate was no longer the highest historical point - 4 of every 5 country had the top PIT rate exceeding 37.5\%, with the maximum of 90\% in Iran. The GDPweighted average top statutory marginal PIT rate was 62\% among 108 countries. National PIT systems were frequently plagued by multiple tax schedules, complicated tax formulas, surcharges, numerous exemptions, and escalating highly-partitioned tax scales. For example, more than a half of all countries had 10 or more tax brackets, up to 68 in Guatemala in 1981. It almost seems that 
Karl Marx’s Manifesto prediction came true: "in the most advanced countries, the following will be pretty generally applicable: a heavy progressive or graduated income tax” (Marx 1847).

However, since 1981, the efficiency arguments forced many governments to make significant changes to their national PIT systems. The GDP-weighted average top statutory marginal PIT rate had fallen from 62\% in 1981 to $42.9 \%$ in 1991 and by 2005 reached a twenty five year low of $36.4 \%$. Similar trends are observed for the number of tax brackets, the use of multiple tax schedules, local taxes, non-standard tax formulas, and non-standard allowances. Another important trend is the increased simplicity of the PIT structure. This has implications for both efficiency, through lower compliance costs, and equity (Slemrod 1992 and Slemrod and Sorum 1984). In this paper, we develop a new time-varying PIT complexity index and show its decline over time among different country groups.

We also calculate the actual marginal and average tax rates at different points of a country's income distribution and find that they too have been trending downward. Another significant contribution of this study is the development of comprehensive country-specific measures of PIT structural progressivity. These measures indicate a continuous decline in income tax progressivity across the world.

Using the reconciled panel data from 189 countries, we examine each trend very carefully for the world as a whole and by country type at different stages of economic development. The evidence we present suggests unequivocally that major tax reforms have been taking place over the last two and half decades. It is clear that tax structures today are flatter and less complex than they were 25 years ago. There is also evidence that a new type of reform process has started and will 
continue for some time into the future. This new wave of reforms is reflected in a growing trend toward the use of one-rate flat personal income taxation. ${ }^{1}$

Despite the general downward trend, we also find some variation across countries in the timing, speed and direction of the observed changes. The most obvious example of this is the increase in actual average and marginal PIT rates in low income countries, which is partly due to the "bracket creep" effect. A similar difference across country group is also evident in the timing of the dramatic decline in the top PIT rates. Low income countries again standout in reducing their top rates much later in the sample period than the other groups.

We begin by providing a quick overview of the data followed by an analysis of major global trends in personal income taxation, in particular, the high frequency of PIT changes, a ubiquitous decline in top statutory PIT rates, a downward movement in actual marginal and average rates at higher levels of individual income, increasing simplicity of national tax systems, decreasing structural PIT progressivity, and the emergence of flat tax schedules.

\section{Data Sources and Sample}

The data analyzed in the paper covers personal income tax structures in 189 current and former countries worldwide for the period 1981 to $2005 .^{2}$ As far as we know, this is the first panel study of this size that analyzes the historical changes that have occurred in personal income tax structures over the last 25 years.

Our dataset is comprehensive and contains the complete national PIT schedules with statutory rates, tax brackets, country-specific tax formulas, basic allowances, standard deductions, tax credits, multiple tax scales, national surcharges, and local taxes. This information allows us to

\footnotetext{
${ }^{1}$ Although this trend is more popular among transitional countries at the moment, there is ongoing debate in other parts of the world about the merits of making the switch.

${ }^{2}$ The number of countries ranges from 108 in 1981 to 180 in 2004.
} 
compute several important variables including country’s statutory rates, number of tax brackets, actual average and marginal tax rates at different points of income distribution, frequency of tax changes, and various measures of PIT progressivity and complexity. In the following sections we give a detailed summary of each variable, including definitions, computation methodology, summary statistics, and trend analysis.

This consolidated PIT dataset was assembled from more than 100 distinct reference books and data sets. Of these, the most important sources are the tax anthologies published by international accounting firms (e.g., PricewaterhouseCoopers, Coopers and Lybrand, etc.) as well as publications and datasets of international organizations (e.g., International Bureau of Fiscal Documentation, OECD, World Bank, International Monetary Fund, etc.) and public policy centers (such as Economist Intelligence Unit, Heritage Foundation, and Fraser Institute). A wide variety of data sources allows for significant cross checking, thus minimizing the amount of errors that one will inevitably encounter in a study of this magnitude. We made every effort to reconcile contradictory reporting to produce a consistent series for each country across time (see Appendix 1 for the description of sources and data reconciliation efforts).

One notable advantage of this consolidated dataset is that it provides a level of world representation that has not been attained in previous studies of tax structures. ${ }^{3}$ Our full sample includes 3613 top statutory PIT rates for 189 current and former countries from 1981 to 2005. This is an average of 145 countries per year. Even in the case of highly data-demanding variables such as tax progressivity measures which require the complete tax schedule, we have non-missing values for 175 countries, or an average of 123 countries per year (from 75 in 1981 to 157 in 2002). To further highlight the representativeness of our sample, we note that $31 \%$ of the countries included

\footnotetext{
${ }^{3}$ Some of the largest samples in earlier studies include 51 marginal PIT rates from developing countries in 1984-1985 (Sicat and Vermani 1988) and 66 top PIT rates in 1980-1989 (Lee and Gordon 2004).
} 
are classified as high income countries, $18 \%$ as upper middle income, $30 \%$ as lower middle income, and $22 \%$ as low income countries. ${ }^{4}$ These countries are located in all populated geographic regions and continents, ${ }^{5}$ and they represent approximately $94 \%$ of the world population and $98.5 \%$ of the world output (or more precisely, 86\% of the world GDP in current U.S. dollars in 1981, 89\% in 1982, 97\% in 1983-1988, and 98-99\% in all subsequent years). ${ }^{6}$

\section{Continuous Tax Reform}

An examination of the dataset reveals a number of remarkable changes in personal income taxation over the last twenty five years. The first important observation is that tax rates, income thresholds, and the overall tax structures are continuously changing. The last column in Table 1 shows that, on average, $45 \%$ of the countries in our sample change at least one element of their national tax scale (statutory rates or tax brackets) every year. Of these countries, about half make full changes by altering both rates and bracket thresholds simultaneously. The share of countries with full changes in PIT was particularly high in the late 1980s relative to other periods. We find very few cases where countries modify their statutory rates while maintaining old thresholds $(2.7 \%$ of the sample). However, the share of countries that adjust tax brackets but keep their statutory rates the same increased significantly in the early 1990s moving from 15\% in the 1986-1990 period to $21 \%$ in the $1991-1995$ period. Changes of this nature might be an indication that countries are increasingly adjusting their tax schedules for inflation.

An investigation of these changes by country type reveals that national PIT scales are changing more frequently in developed countries (62\% of countries in the respective category per

\footnotetext{
${ }^{4}$ Country categories are defined using the World Bank country classification based on historical (time-varying) income thresholds. For example, the income thresholds used for the 2005 classification are as follows: low income, $\$ 875$ or less, upper middle income, \$876-\$3465, upper middle income, \$3466-\$10725, and high income, \$10725 or more.

${ }^{5}$ The regional breakdown is as follows: Africa - 48 countries, Asia and Oceania - 31, Central and South America - 35, Eurasia - 16, Europe - 43, Middle East - 12, and North America - 4.

${ }^{6}$ The major economies with missing PIT rates in the early 1980s are former USSR in 1981-1982 and Italy in 1981.
} 
year) followed by upper middle income countries (44\%), lower middle income countries (42\%), and low income countries (29\%). The significant number of developed countries that went through major tax reforms in the late 1980s explains the spike in the share of high income countries with full changes in their tax scales during the 1986-1990 period (42.7\%).

The difference between high and low income countries is especially striking with respect to the share of countries that alter only thresholds but not rates. From Table 1 it becomes apparent that low income countries neglect to adjust their tax brackets for inflation over the whole considered period. This is also true for the middle income countries in the 1980s. Without such inflationary adjustments, the tax structure may become less equitable if taxpayers are being pushed into higher tax brackets with no accompanying increase in real income. This is known as the "bracket creep" effect. Even if top statutory PIT rates are falling, the core taxpayers may actually experience an increase in marginal rates in an inflationary environment that is commonly present in less developed economies. The "bracket creep" effect has been shown not only to raise actual rates but also to encourage tax evasion in the U.S. prior to the introduction of threshold indexation in 1985 (Crane and Nourzad 1986).

Apart from the inflationary adjustments, another explanation for continuous changes in tax rates and brackets could be that countries are simply experimenting in an attempt to find the best tax structure. Identifying the best tax structure, however, is a normative matter, which can affect the changes in different ways. Countries that are concerned about equity issues, for example, may want to increase their tax rates while those more concerned about efficiency may reduce them. Whatever the motivation behind the high frequency changes, however, one might expect some negative 
feedback for efficiency. This follows from the fact that a constantly changing tax schedule adds uncertainty to the tax system which is likely to increase complexity and hence reduce efficiency. ${ }^{7}$

The important question for us is whether these changes are simply transitory in nature or is there some well defined direction of change. If changes are being made on the grounds of efficiency, then one may expect persistent trends to develop over time as countries try to improve the efficiency of their tax structures by reducing rates. The remainder of the paper will give a detailed analysis of the resulting trends that have developed over time.

\section{Top Statutory PIT Rates Fall}

One of the frequently cited variables of any income tax system is the top statutory personal income tax (PIT) rate. This is a legally determined marginal tax rate applicable to the top bracket of the income tax schedule. This particular tax rate has occasionally been used in empirical crosscountry research as a proxy variable for tax progressivity or as a way of assessing the overall excess tax burden (e.g., Johnson, Kaufmann and Zoido-Lobaton 1998, Friedman et al 2000, among others).

Table 2 and Figure 1 illustrate how the average top statutory tax rate has dropped considerably over the last twenty five years. This decline was especially pronounced for the GDPweighted trend which is more representative of the world economy. ${ }^{8}$ One interesting observation is that the most dramatic change occurred during the late eighties and early nineties. Referring to the second column of Table 2, we see that the weighted average top statutory PIT rate fell from a high of $62 \%$ in 1981 to $56.3 \%$ in 1986 . During the ensuing eight year period (1986 - 1993), however, the PIT rate plunged by approximately 16 percentage points. The PIT rate then increased slightly by 2 percentage points before resuming its downward trend in 1996. Since then, the decline has

\footnotetext{
${ }^{7}$ Constantly changing features of the tax schedule cause individuals to be uncertain about their tax liability and thus increase compliance and administrative costs (Slemrod 1992).

${ }^{8}$ Gross domestic product in U.S. dollars at 1990 prices is used as weights.
} 
continued, with average top statutory rates sliding a further 6.5 percentage points over the next 10 years. Together these changes represent a sizeable $41.2 \%$ decline in the weighted top PIT rate from a high of $62 \%$ in 1981 to a low of $36.4 \%$ in 2005.

Further evidence in support of the worldwide downward trend is reported in Table 3 where we observe that only $17 \%$ of unweighted top PIT rates were in excess of $40 \%$ in 2001-2005 compared to over $71 \%$ during the early 1980s. The share of countries with top PIT rates in excess of $60 \%$ plummeted from about a quarter in 1981 to less than $1 \%$ in 2005 . The lower non-zero rates ( $1 \%$ to $40 \%$ ), on the other hand, became more popular as the percentage of countries falling into these categories increased from approximately 15\% to over 73\% between 1981 and 2005.

The reader will notice that there are two changes in the weighted PIT trend that align perfectly with well known tax changes in the U.S. These are the 1986 and 1993 tax reforms which reduced and increased the top PIT rates respectively. Column two of Table 2 indicates that the weighted top PIT rate fell by approximately 6 percentage points between 1986 and 1987 . Similarly, the 2 percentage point increase in the top PIT rate between 1993 and 1994 coincides with the 1993 U.S. tax reform. ${ }^{9}$ This casual observation would imply, incorrectly, that the larger countries, as measured by GDP, are driving these trends with little or no change taking place elsewhere in the world. However, the summary statistics presented in Table 4 and Figure 1 show clearly that the changes are ubiquitous. From Table 4, for example, we are able to highlight that each country category experienced a significant decline in the GDP-weighted top PIT rate. The greatest decline was among the upper middle income countries, followed by low, lower middle and high income countries respectively. By 2005, upper middle income countries had the lowest top PIT rates on average.

\footnotetext{
${ }^{9}$ These “coincidences” aren’t readily observable for the unweighted means.
} 
While the evidence in Panel A proves that the downward movement in top PIT rates was universal, the trend coefficients in Panel B also suggest that the major changes appear to be sequential. What started as top tax rate cuts in high income countries during the early and mid 1980s was spread to middle income countries during the late 1980s and early 1990s before eventually reaching low income countries in the late 1990s.

\section{Actual PIT Rates Fall in High and Middle Income Countries}

The top statutory PIT rate is generally quoted in impressionistic comparisons of national income tax schedules, and, in particular, as a proxy for the tax burden in some empirical research. In a sense, it is easy to see why this rate is so widely used, as it is potentially the maximum marginal tax rate facing wealthiest taxpayers. However meaningful the top rate might be, it is also important to examine the trends in PIT rates at other points of the income distribution that are more relevant to the majority of population. ${ }^{10}$ The problem though, is that it is practically unfeasible to find the actual income distribution for the large number of countries over the 25-year period. Alternatively, we can use a country's GDP per capita and its multiples as a comparable income base. For example, for each country in our sample, we can calculate the marginal rates for the level of individual income equivalent to 1, 2, 3, and 4 times GDP per capita by using the national PIT scale. $^{11}$

In addition to having rates at different levels of individual earnings, our data also allow us to calculate the actual marginal tax rates that are generally more preferred to the statutory rates dictated by national tax schedules. It is not unusual for these two rates to differ significantly. A

\footnotetext{
${ }^{10}$ In high income countries the top statutory PIT rate is applicable, on average, to the level of income equivalent to the triple of a country's GDP per capita. In contrast, the ratio of the top threshold to a country's GDP per capita is about 18 in upper middle income countries, 47 in lower middle income countries, and 83 in low income countries. In other words, the top rates in less developed economies are not even relevant to the majority of domestic high earners and entrepreneurs, with the exception of the small number of expatriates and wealthiest local elite.

${ }^{11}$ This approach was also used by Sicat and Vermani (1988) in comparing marginal rates across 51 developing countries.
} 
local tax, national surtax, or additional tax schedules can raise the actual marginal tax rate above the officially stated rate. Personal deductions and tax credits, on the other hand, can lower the actual marginal tax rate below the legal rate. To estimate actual marginal tax rates for each country in our sample, we first calculate taxable income for 100 different levels of pre-tax income that are evenly spread in the range from $4 \%$ to $400 \%$ of a country's GDP per capita. Taxable income excludes standard deductions, basic personal allowances, and employee/wage allowances, which are unconditionally applicable to all single, employed taxpayers. Next, we apply the tax schedule and, whenever relevant, particular tax formulas to the taxable income in order to compute the tax liability for each income level. ${ }^{12}$ The tax liability also includes local taxes and major national surtaxes if altogether they exceed $5 \%$ of the taxable income. ${ }^{13}$ The final tax liability figure is adjusted by subtracting the tax credits that are universally applicable to single taxpayers. Finally, the actual marginal rates are calculated as $\Delta$ tax liability / $\Delta$ income for each of the 100 values of gross income. $^{14}$

Using tax liability figures, we also compute the average tax rate as the ratio of total tax liability to gross income for each level of income. It is important to emphasize that the average rate is the tax rate that the individual taxpayers face or are supposed to pay under current tax laws, not the rate they choose to pay by means of underreporting their income. As such, the average tax rate gives an upper bound on the effective rate paid by individuals under the PIT.

\footnotetext{
${ }^{12}$ In 418 country-year cases we had to use non-standard country-specific procedures in computing tax liability. For example, countries may have multiple layers of taxes (Cameroon, Denmark, etc.), an additional schedule for salaries (Egypt, Senegal, etc.), or particular tax computation formulas (e.g., Cote d'Ivoire and Germany).

13 The methods used to incorporate local taxes vary from using simple average rates (e.g., Denmark, Finland, and Sweden) to applying separate local tax schedules such as in Canada (Ontario), Japan, and Switzerland (Zurich).

${ }^{14}$ For the level of gross income equivalent to a country's GDP per capita, actual and statutory marginal rates are approximately the same in $66 \%$ cases (within one percentage point deviation), the statutory rate is greater in $29 \%$ cases, and it is less in $5 \%$ cases. The similarities between actual and statutory rates tend to increase with the level of gross income.
} 
Figure 2 shows that in any given year the marginal rates are higher than their respective average rates and that both average and marginal rates increase with the level of income. These are the two main indications that the personal income tax structure for most of the countries remains progressive. More important for the current discussion, however, are the observed trends for the various rates. Irrespective of the rate chosen, one observes a clear downward trend over the sample period. Also, all of the variables show that the greatest downturn in the tax rates took place during the mid to late eighties, with a consistent but moderate decline in the subsequent years.

Also important to note is that there is some amount of convergence between the actual rates for higher and lower income levels. That is, while both high-income rates and low-income rates trended downward throughout the sample period, the high-income rates (for the income corresponding to quadruple of a country’s GDP per capita) fell at a much faster rate. For example, marginal tax rates (MTR) at $y$, where $y$ denotes GDP per capita, fell by -0.51 percentage points per year whereas MTR at $4 \cdot y$ went down by -0.78 percentage points per year; the difference in the rates of decline is statistically significant at all conventional levels of significance. A similar convergence result is obtained with respect to the annual decline in average rates (-0.33 percentage point decline at $y$ vs. -0.59 at $4 \cdot y$ ). This apparent convergence could be an indication that the tax reforms have reduced the progressivity of income tax structures that we examine further below.

Thus, if we take a worldwide weighted average, we observe a tendency of national tax systems toward lower actual marginal and average PIT rates at different points of the income distribution, and this tendency seems particularly strong at the higher levels of individual earnings. While it is true on average, this conclusion does not hold for the poorest countries. In Table 5 we report the estimated trend coefficients by country category at four income levels. With the exception of the average rate at $y$ for the upper middle income category, high and middle income countries have declining actual PIT rates over the 25-year period. In concordance with an earlier 
observation, the decline in both marginal and average rates was stronger for higher levels of individual earnings. Perhaps the most interesting result in Table 5 is that the least developed countries had either no change or an increase in rates throughout the sample period. These results are not that surprising in light of the evidence presented in the previous section on the frequency with which the PIT structure changes. Since the low income countries make very few changes to their bracket thresholds and experience much higher inflation than the other groups of countries, it is predictable that the actual rates are increasing over time, especially for the upper middle class. Households with below median income are often not liable (and not able) to pay any taxes because their income is generally lower than the first tax threshold. Therefore, the beneficiaries of the decrease in the top statutory PIT rate in the poor countries have to be extraordinarily rich relative to the rest of population.

Thus, the trends discussed so far make it clear that the observed downward movement in actual PIT rates is influenced significantly by more developed economies.

\section{Trend Toward Simplicity}

In addition to the downward trend in statutory and actual PIT rates, there has also been a consistent drive toward PIT simplicity among the countries of the world. This change compliments the efficiency-driven downward trend in PIT rates since an exceedingly complex tax structure is likely to encourage tax evasion or unofficial economy transactions as individuals seek to reduce their taxable income. Furthermore, there are other social costs imposed on the society by having a complex tax system, including the costs of filing the returns (both time and monetary), efforts to calculate deductions and allowances as well as other efforts to reduce taxable income. Slemrod and Sorum (1984) show that these costs were very high for the U.S. PIT system in 1982 consuming approximately $5-7 \%$ of tax revenues generated in that year. There is also a trade off between simplicity and other characteristics of the tax structure. This is true especially where the efforts to 
distinguish among taxpayers in achieving a more equitable distribution make the existing tax structure more complex (Slemrod 1992). Therefore, the trend in complexity is important since it has implications for both equity and efficiency.

To capture the complexity trend we first constructed a complexity index. This index is computed on a zero to ten scale (with zero being less complex) using certain characteristics of the personal income tax structure that contribute to tax complexity such as allowances, tax credits, multiple tax schedules, special tax formulas, local taxes, national surtaxes, and the number of tax brackets. A list of the factors that make up the complexity index and their respective scores are reported in Table 6. The logic there is that having no allowances, for example, is considered to be less complex than having allowances, while having allowances that depend on the spouse's employment participation is considered more complex than having a standard allowance. ${ }^{15}$ Similarly, having a single tax schedule is simpler than having multiple schedules since a single tax schedule eliminates any confusion as to which schedule individuals should use when filing their tax returns. ${ }^{16}$ Having special formulas for tax computations also adds to the tax complexity as it often requires extra rules, regulations and definitions to make these formulas work.

Other factors contributing to complexity, though in varying degrees, are surtaxes and local taxes. The surtax score is straightforward, with 0 meaning there is no surtax and 1 denoting that one is present. In the case of local taxes, a 0 is assigned if there are no local taxes, a 1 if the local taxes are below $5 \%$ of taxable income, and a 2 if local taxes are $5 \%$ or above. The last, but not the least, contributing factor is the excessive partitioning of personal income into multiple tax brackets. For this category, we assign a 0 for no tax brackets, a 1 for 1-2 tax brackets, a 2 for 3-5 tax brackets,

\footnotetext{
${ }^{15}$ For this factor we assign 0 if there are no allowances, deductions, or tax credits; 1 for standard allowances, deductions, and tax credits; and 2 for more complex cases. Personal allowances and tax credits are considered standard if they are applicable to the taxpayer, spouse, and/or children without any restricting conditions (such as age, children being at school, spouse not working, etc.).

${ }^{16}$ We assign 1 if a country has several tax schedules that depend on occupation, industry, location, marital status and other characteristics of a resident taxpayer.
} 
and a 3 for 6 or more tax brackets. Therefore, the least complex tax structure would occupy the zero (0) column of Table 6 for each factor, while the most complex would occupy the right most nonempty cell in each row.

Before discussing the trends it is important to note a few caveats. Obviously, the relative weight of each individual component in the complexity index is subjective, and we leave the sensitivity analysis of alternative weighting schemes for future research. The index does not take into account some other important dimensions of tax complexity such as clarity of tax laws and regulations, costs of tax planning and paperwork, the time needed to submit declarations, the number of exemptions and itemized deductions, and other analogous factors, which are hard to measure even for one country, much less for many countries. It is virtually impossible to collect time-varying data on these kinds of factors for the large $(170+)$ number of countries. Despite these limitations, our index does provide useful and comparable cross-country information on several key dimensions of income tax complexity, which is worth describing.

With the above caveats we point out that the tax systems around the world have become less complex than they were in 1981. Tables 2 and 7 provide information on the complexity index as well as its different components. We observe for example, that both GDP-weighted (Table 2) and unweighted (Table 7) averages of the complexity index fell over the sample period. The significance of these changes follows closely the pattern of the PIT changes discussed above. That is, the major changes took place during the late 1980s and early 1990s.

A notable pattern is observed when we look at the complexity index by income group (Figure 3). The weighted average for the low income countries fluctuated between 4.07 and 4.85 points throughout the sample period with standard deviation of 0.88 and a statistically insignificant trend coefficient. In other words, we do not find an apparent trend for low income countries over the 25-year period. High income countries, on the other hand, experienced a sizeable decline in the 
complexity index in the late 1980s followed by an extended period of no noticeable trend. But the countries where most of the changes have occurred were the middle income countries that went through a significant 30\% drop in the complexity index, mostly in the early 1990s.

In an effort to identify the major contributing factors to the observed complexity trend we also analyze the individual components of the index. First, we note that approximately $49 \%$ of the sample had more than 10 tax brackets in the 1981-1985 period with approximately 9\% having more than 20 brackets (see Table 8). This is in comparison to 5.5\% and $0.4 \%$ in the 2001-2005 period, respectively. While the 6-9 range gained marginally, increasing by a total of 3 percentage points, the 1-3 and 4-5 ranges became the norm. As of 2005, approximately 55\% (23\% and $32 \%$ respectively) of countries fell into these ranges, while the zero range experienced a decline of approximately 5 percentage points. Both unweighted and GDP-weighted trends in Figure 4 indicate that the steep decline in the average number of tax brackets was worldwide. Although there was significant variation in the number of brackets at the beginning of the sample period, the average number of brackets since 1995 has remained around 4-6 for all country categories.

A similar trend is observed for allowances although with less significant changes. For example, whereas an average of $53 \%$ of countries had non-standard allowances or tax credits in the first five year period of the sample, this number decreased to $40 \%$ in the last five year period. Again, the largest changes took place in the first two periods where the share of non-standard allowances fell by $9 \%$ and $14 \%$ respectively. There is also a noticeable decline in the use of surtaxes and high local tax rates (5\% of taxable income or greater) and a corresponding increase in the use of low local tax rates. Similarly, the percentage of the sample using non-standard tax formulas fell by 10 percentage points or over 50\% between 1981 and 2005 . Unlike the other components, the use of multiple schedules increased slightly between the first and second period before also showing a steady decline from $22 \%$ in the second period to $17 \%$ in the last. 
Thus, our discussion has shown that the complexity index variables have exhibited strong downward trends over the last quarter century. Certainly, the steep drop in the average number of tax brackets, the gradual elimination of surtaxes, and the dwindling use of multiple tax schedules, non-standard allowances and tax formulas has moved countries toward simpler income tax systems.

\section{Trends in Structural Progressivity}

The evidence so far shows that there has been a significant shift towards more simple income tax structures and lower tax burden, especially at the top of the income distribution. These changes can justifiably be assumed to have a negative effect on the structural progressivity of the income tax system. The term structural progressivity is introduced by Musgrave and Thin (1948) to denote changes in the calculated (nominal) tax burden along the income distribution, as opposed to the effective progressivity that depicts changes in actual income inequality.

To assess the structural PIT progressivity for each country in the sample, we calculate the marginal rate progression (MRP) and average rate progression (ARP). Unlike Musgrave and Thin (1948), whose progressivity measures vary over the income distribution, we develop a single, comprehensive measure for each country using the following procedure. First, we compute marginal and average rates for each country and each year at 100 different levels of pre-tax income that are evenly spread in the range from $4 \%$ to $400 \%$ of a country's GDP per capita (the calculation process is described earlier in the text). These variables are then used to construct marginal and average rate progression (MRP1 and ARP1, respectively) by estimating the slope coefficient from regressing marginal (or average) rates on the log of gross income for the income distribution up to 4.y income. For example, ARP1 for Canada in 2005 is the estimated slope coefficient from the regression of average tax rates in 2005 on the log of gross income using 100 data points that are formed around Canada's GDP per capita in a given year. The tax structure is interpreted as progressive, proportional or regressive if the slope is positive, zero, or negative, respectively. Thus, 
in order to get a single, comprehensive measure we had to impose a linearity restriction on the relationship between rates and income levels. In an effort to capture some nonlinearity of these measures, we also calculated MRP2 and ARP2 for the middle portion of income distribution in the range from $100 \%$ to $300 \%$ of a country’s GDP per capita.

Tables 2 and 9 provide the GDP-weighted means of the progressivity measures over the sample period. Starting with Table 2 we observe that both progressivity measures were positive for the full sample period indicating that the tax structures remain progressive despite many reforms. It is also shown that the structural progressivity declined over the sample period. We note, for example, that the MRP1 fell from 0.154 in 1981 to 0.096 in 2005, while the ARP1 fell from 0.106 in 1981 to 0.064 in 2005. When examined on a period basis, in Table 9, we observe a noticeable decline in all progressivity measures throughout the late 1980s and early 1990s. This is consistent with our earlier discussion which highlighted these years as periods of significant tax reforms.

We also note that the structural progressivity of the income tax system is greater in the middle of the income distribution (MRP2 and ARP2) than for the broader distribution (MRP1 and ARP1), thus confirming the non-linearity of the progressivity measures.

Along with the average worldwide trend toward less structural progressivity, we also observe significant variation in the progressivity dynamics across country type. Panel B in Table 9 shows that countries that experienced the strongest decline in the progressivity measures belong to the high income and upper middle income categories. The downward trend slope is much smaller in lower middle income countries, and the trend is positive and statistically significant in poorest developing economies. This result is not surprising given our earlier finding of an increase in actual tax rates at the top of the individual distribution in low income countries.

An interesting question to ask is what do these trends mean for equity? It might seem that countries have been more willing to reduce excess tax burden in their economy to achieve greater 
efficiency at the expense of greater equity. However, the equity outcomes of these global tax changes are not clear; a reduction in structural tax progressivity does not necessarily imply less equity. If the tax reform increases productivity and reduces tax evasion, then a reduction in structural progressivity may actually result in higher effective progressivity, and hence greater equity, assuming that the redistribution of the increased tax revenues is progressive or pro-poor. But even when redistribution from rich to poor does not occur, lower taxes on rich could in principle decrease true net income inequality if the share of hidden income among the rich is large while the elasticity of true income/productivity is small relative to the elasticity of hidden income with respect to tax changes. Duncan and Sabirianova Peter (2008), for example, show that while structural progressivity reduces observed inequality (based on reported income), its effect on true income inequality depends on the level and responsiveness of tax evasion.

\section{Global Flat Tax Revolution}

The outmost case of zero (or near to zero) structural progressivity deserves special consideration. It occurs when a country has either no $\operatorname{tax}^{17}$ or a one-rate flat tax that is not dependent on where an individual falls in the income distribution. The case of the flat personal income tax is particularly interesting as the number of countries introducing the flat tax rate is rapidly growing in recent years. The flat tax may or may not be accompanied by an allowance or an additional zero-rate threshold, which could make progressivity measures different from zero.

During the 1981-1985 period only $1.6 \%$ of countries had flat rate income tax schedules. Over the next ten years this number doubled to 3.67\% and by 2001-2005 it had almost quadrupled

\footnotetext{
${ }^{17}$ The number of countries with zero tax was relatively stable throughout the sample period, between 15 and 17 countries. These countries include some of the oil countries (e.g., Brunei Darussalam, Saudi Arabia, United Arab Emirates, etc.) and famous offshore islands and tax heavens (e.g., Bahamas, Bermuda, British Virgin Islands, Cayman Islands, etc.).
} 
to $6.23 \%$. By 2005, fourteen countries worldwide have adopted the one-rate personal income tax, eleven of which are middle income countries.

While still in its early stages, the trend toward flatter taxes continues to gather strength as the list of countries adopting the flat tax expands. Since 1994, for example, when Estonia adopted the first flat tax in Europe, Georgia, Latvia, Lithuania, Russia, Romania, Slovakia, Ukraine, and Serbia have all adopted flat tax rate schedules as of January 1, 2005. By 2008, the number of flat tax countries is expected to increase to 21 as seven more countries (Albania, Kazakhstan, Kyrgyzstan, Mongolia, Montenegro, Poland, and Republic of Macedonia) introduced or announced introduction of the flat PIT rate in 2007-2008. With Russia serving as a model success story (Gorodnichenko et al, 2008), there continues to be significant debate among countries about the merits of making the switch to a flat tax. Given these facts, one can only conclude that the long term trend towards lower tax rates and broader tax bases may be entering a new era of change where countries move away from their conventional stair stepped progressive income tax schedules to simpler, flatter tax structures.

\section{Conclusion}

The analysis presented in this paper identifies and determines the direction of a momentous change in the world's tax systems. We highlighted a tax reform process in which governments have moved away from complex, progressive tax systems featuring multiple tax brackets and escalating stair step tax rates to simpler, flatter tax schedules distinguished by fewer tax brackets and lower tax rates. In fact, taxpayers on average face lower personal income tax rates and simpler rate structures than they did twenty five years ago. This transformation suggests an epic and ubiquitous change in fiscal policy.

As the trends continue to play out, we also see a nascent secondary trend emerging where the conventional stair-stepped tax schedule is being replaced by a flat tax. The recent acceleration 
in this trend began with Estonia's adoption of a flat tax in 1994 and has since spread to other postcommunist countries. As noted earlier, the number of countries using flat tax rates has soared since 1981 but still remains relatively small at about $12 \%$ of the sample countries by 2007 . However, at the writing of this paper, other countries such as Croatia, Czech Republic, Greece, and Mexico are giving a flat tax schedule serious consideration. It seems to us, therefore, a reasonable supposition, that the trend toward flat taxes will continue for the next several years. Whether or not this second trend continues, exceptional long term changes have already transformed the tax systems of the world.

The observed trends raise a number of questions that we hope to address in future work. For example, why was there such a dramatic shift in tax policy over this 25-year period? According to the median voter hypothesis, the higher income inequality, and hence the lower position of the median voter in the income distribution, creates more pressure for higher tax progressivity and more redistribution (Meltzer 1981). Do the global trends toward lower rates and less progressive tax systems suggest that the median voter's position in the income distribution improved over time or that the voter has been loosing power to the bureaucrats and politicians?

Also, what are the implications for efficiency, equity, and growth? Conceivably, flatter tax structures could reduce the excess burden without necessarily sacrificing equity. Davies and Hoy (2002), for example, argue that moving from a graduated tax schedule to a flat tax improves equity. Furthermore, flatter, simpler tax systems can possibly increase the efficiency of the tax system by broadening the tax base as well as improving tax compliance. ${ }^{18}$ On the other hand, flatter tax systems can lead to less equity as more of the tax burden is redistributed from the wealthier

\footnotetext{
${ }^{18}$ Gorodnichenko et al (2008). Feldstein (1995) demonstrated that the sensitivity of taxable income with respect to changes in the marginal tax rate is much larger than can be explained by estimated labor supply elasticities. The implication then is that there are other behavioral responses at work.
} 
taxpayers to the lower and middle income classes. The effect of these changes on growth is also of grave importance. To the extent that efficiency has increased, we might expect a positive effect on growth. If inequality also increased, however, then the effect on growth may be ambiguous. That is, increased inequality arising from the tax reform may or may not lead to increased growth (Milanovic 2000, Persson and Tabellini 1994, Perotti 1992, among others). As such, the net effect on equity, efficiency, and growth remains an empirical question.

\section{References}

Crane, Steven and Farrokh Nourzad, 1986. "Inflation and Tax Evasion: An Empirical Analysis,” Review of Economics and Statistics 68(2): 217-223.

Davies, James and Michael Hoy, 2002. “Flat Rate Taxes and Inequality Measurement,” Journal of Public Economics 84(1): 33-46.

Duncan, Denvil and Klara Sabirianova Peter, 2008. “Tax Progressivity and Income Inequality,” unpublished paper.

Feldstein, Martin, 1995. “The Effect of Marginal Tax Rates on Taxable Income: A Panel Study of The 1986 Tax Reform Act,” Journal of Political Economy 103 (3): 551 - 572.

Friedman, Eric; Johnson, Simon; Kaufmann, Daniel and Pablo Zoido-Labton, 2000. "Dodging the Grabbing Hand: The Determinants of Unofficial Activity in 69 Countries,” Journal of Public Economics 76(3), 459-493.

Gorodnichenko, Yuriy; Martinez-Vazquez, Jorge and Klara Sabirianova Peter, 2008. "Myth and Reality of Flat Tax Reform: Micro Estimates of Tax Evasion Response and Welfare Effects in Russia,” NBER Working Paper, No. 13719.

Johnson, Simon; Kaufmann, Daniel and Pablo Zoido-Lobaton, 1998. "Regulatory Discretion and the Unofficial Economy,” American Economic Review 88(2): 387-392.

Lee, Young and Roger Gordon, 2004. “Tax Structure and Economic Growth,” Journal of Public Economics 89(5-6): 1027-1043.

Meltzer, Allan and Scott Richard, 1981. “A Rational Theory of the Size of Government,” Journal of Political Economy 89(51): 914 - 927.

Milanovic, Branko, 2000. “The Median-Voter Hypothesis, Income Inequality, and Income Redistribution: An Empirical Test with the Required Data,” European Journal of Political Economy 16 (3): 367-410. 
Musgrave, Richard and Tun Thin, 1948. “Income Tax Progression, 1929-48,” Journal of Political Economy 56(6): 498-514.

Perotti, Roberto, 1992. "Income Distribution, Politics and Growth,” American Economic Review 82(2): 311-316.

Persson, Torsten and Guido Tabellini, 1994. “Is Inequality Harmful for Growth?,” American Economic Review. 84(3): 600-621

Seligman, E.R.A., 1908. "Progressive Taxation in Theory and Practice,” American Economic Association Quarterly 9(4): 1-334.

Sicat, Gerardo and Arvind Vermani, 1988. "Personal Income Taxes in Developing Countries,” World Bank Economic Review 2(1): 123-138.

Slemrod, Joel, 1992. "Did the Tax Reform Act of 1986 Simplify Tax Matters?" Journal of Economic Perspective 6(1): 45-57.

Slemrod, Joel and Nikki Sorum, 1984. "The Compliance Cost of the U.S. Individual Income Tax System," National Tax Journal 37(4): 461-474.

Young, Peyton, 1990. "Progressive Taxation and Equal Sacrifice,” American Economic Review 80(1): 253-266. 
Table 1: Frequency of Changes in PIT Schedule by Period and Country Category

\begin{tabular}{|c|c|c|c|c|c|}
\hline Period & High Income & $\begin{array}{l}\text { Upper } \\
\text { Middle } \\
\text { Income }\end{array}$ & $\begin{array}{l}\text { Lower Middle } \\
\text { Income }\end{array}$ & Low Income & Total \\
\hline \multicolumn{6}{|c|}{ Share of countries with no yearly changes in statutory rates and thresholds } \\
\hline $1981-1985$ & 0.348 & 0.667 & 0.735 & 0.661 & 0.592 \\
\hline $1986-1990$ & 0.298 & 0.560 & 0.623 & 0.671 & 0.526 \\
\hline $1991-1995$ & 0.419 & 0.525 & 0.500 & 0.606 & 0.506 \\
\hline $1996-2000$ & 0.439 & 0.491 & 0.545 & 0.747 & 0.558 \\
\hline $2001-2005$ & 0.378 & 0.576 & 0.571 & 0.782 & 0.574 \\
\hline All years & 0.383 & 0.552 & 0.583 & 0.711 & 0.550 \\
\hline \multicolumn{6}{|c|}{ Share of countries with yearly changes in both statutory rates and thresholds } \\
\hline $1981-1985$ & 0.359 & 0.117 & 0.173 & 0.220 & 0.227 \\
\hline $1986-1990$ & 0.427 & 0.307 & 0.239 & 0.224 & 0.303 \\
\hline $1991-1995$ & 0.199 & 0.273 & 0.259 & 0.257 & 0.245 \\
\hline $1996-2000$ & 0.269 & 0.202 & 0.175 & 0.139 & 0.198 \\
\hline $2001-2005$ & 0.311 & 0.196 & 0.186 & 0.129 & 0.210 \\
\hline All years & 0.306 & 0.223 & 0.210 & 0.179 & 0.233 \\
\hline \multicolumn{6}{|c|}{ Share of countries with yearly adjusted thresholds but unchanged statutory rates } \\
\hline $1981-1985$ & 0.250 & 0.200 & 0.071 & 0.102 & 0.155 \\
\hline $1986-1990$ & 0.258 & 0.120 & 0.130 & 0.059 & 0.152 \\
\hline $1991-1995$ & 0.331 & 0.152 & 0.209 & 0.101 & 0.207 \\
\hline $1996-2000$ & 0.269 & 0.254 & 0.245 & 0.101 & 0.215 \\
\hline $2001-2005$ & 0.272 & 0.207 & 0.229 & 0.082 & 0.196 \\
\hline All years & 0.277 & 0.191 & 0.185 & 0.090 & 0.190 \\
\hline $\mathrm{N}$ & 703 & 440 & 677 & 581 & 2401 \\
\hline
\end{tabular}

Notes: Frequencies are computed on the sample of countries with a complete national PIT schedule in both current and previous years. 
Table 2: Global Trend in Main Personal Income Tax Variables

\begin{tabular}{|c|c|c|c|c|c|c|}
\hline & \multirow{2}{*}{$\begin{array}{c}\text { Unweighted } \\
\text { Top PIT } \\
\text { Rate } \\
\end{array}$} & \multicolumn{5}{|c|}{ Weighted } \\
\hline & & $\begin{array}{c}\text { Top PIT } \\
\text { Rate }\end{array}$ & $\begin{array}{c}\text { Number of } \\
\text { Brackets }\end{array}$ & Complex & MRP1 & ARP1 \\
\hline 1981 & $\begin{array}{c}46.775 \\
(23.775)\end{array}$ & $\begin{array}{c}62.009 \\
(14.006)\end{array}$ & $\begin{array}{l}14.674 \\
(6.570)\end{array}$ & $\begin{array}{c}6.413 \\
(1.242)\end{array}$ & $\begin{array}{c}0.154 \\
(0.057)\end{array}$ & $\begin{array}{c}0.106 \\
(0.041)\end{array}$ \\
\hline 1982 & $\begin{array}{c}48.192 \\
(23.364)\end{array}$ & $\begin{array}{c}57.265 \\
(13.796)\end{array}$ & $\begin{array}{l}13.245 \\
(6.340)\end{array}$ & $\begin{array}{c}6.266 \\
(1.288)\end{array}$ & $\begin{array}{c}0.138 \\
(0.048)\end{array}$ & $\begin{array}{c}0.102 \\
(0.038)\end{array}$ \\
\hline 1983 & $\begin{array}{c}47.913 \\
(23.219)\end{array}$ & $\begin{array}{c}57.918 \\
(13.440)\end{array}$ & $\begin{array}{l}12.984 \\
(6.477)\end{array}$ & $\begin{array}{c}6.261 \\
(1.241)\end{array}$ & $\begin{array}{c}0.139 \\
(0.047)\end{array}$ & $\begin{array}{c}0.101 \\
(0.037)\end{array}$ \\
\hline 1984 & $\begin{array}{c}45.930 \\
(23.469)\end{array}$ & $\begin{array}{c}56.736 \\
(12.289)\end{array}$ & $\begin{array}{l}12.503 \\
(6.256)\end{array}$ & $\begin{array}{c}6.308 \\
(1.185)\end{array}$ & $\begin{array}{c}0.138 \\
(0.046)\end{array}$ & $\begin{array}{c}0.100 \\
(0.037)\end{array}$ \\
\hline 1985 & $\begin{array}{c}45.102 \\
(22.959)\end{array}$ & $\begin{array}{c}56.503 \\
(12.234)\end{array}$ & $\begin{array}{l}12.413 \\
(6.199)\end{array}$ & $\begin{array}{c}6.282 \\
(1.203)\end{array}$ & $\begin{array}{c}0.140 \\
(0.047)\end{array}$ & $\begin{array}{c}0.102 \\
(0.037)\end{array}$ \\
\hline 1986 & $\begin{array}{c}44.083 \\
(22.511)\end{array}$ & $\begin{array}{c}56.280 \\
(12.183)\end{array}$ & $\begin{array}{l}12.246 \\
(5.994)\end{array}$ & $\begin{array}{c}6.289 \\
(1.250)\end{array}$ & $\begin{array}{c}0.137 \\
(0.045)\end{array}$ & $\begin{array}{c}0.099 \\
(0.035)\end{array}$ \\
\hline 1987 & $\begin{array}{c}41.307 \\
(21.851)\end{array}$ & $\begin{array}{c}50.635 \\
(13.054)\end{array}$ & $\begin{array}{c}8.732 \\
(5.631)\end{array}$ & $\begin{array}{c}6.013 \\
(1.162)\end{array}$ & $\begin{array}{c}0.127 \\
(0.043)\end{array}$ & $\begin{array}{c}0.093 \\
(0.034)\end{array}$ \\
\hline 1988 & $\begin{array}{c}40.323 \\
(21.135)\end{array}$ & $\begin{array}{c}47.153 \\
(15.881)\end{array}$ & $\begin{array}{c}6.760 \\
(3.806)\end{array}$ & $\begin{array}{c}5.970 \\
(1.104)\end{array}$ & $\begin{array}{c}0.114 \\
(0.042)\end{array}$ & $\begin{array}{c}0.084 \\
(0.031)\end{array}$ \\
\hline 1989 & $\begin{array}{c}39.238 \\
(20.771)\end{array}$ & $\begin{array}{c}44.139 \\
(15.195)\end{array}$ & $\begin{array}{c}6.104 \\
(3.740)\end{array}$ & $\begin{array}{c}5.695 \\
(1.323)\end{array}$ & $\begin{array}{c}0.112 \\
(0.045)\end{array}$ & $\begin{array}{c}0.083 \\
(0.031)\end{array}$ \\
\hline 1990 & $\begin{array}{c}37.372 \\
(19.527)\end{array}$ & $\begin{array}{c}42.345 \\
(13.471)\end{array}$ & $\begin{array}{c}5.818 \\
(3.646)\end{array}$ & $\begin{array}{c}5.677 \\
(1.326)\end{array}$ & $\begin{array}{c}0.113 \\
(0.045)\end{array}$ & $\begin{array}{c}0.082 \\
(0.029)\end{array}$ \\
\hline 1991 & $\begin{array}{c}36.139 \\
(19.105)\end{array}$ & $\begin{array}{c}42.937 \\
(12.807)\end{array}$ & $\begin{array}{c}5.534 \\
(3.712)\end{array}$ & $\begin{array}{c}5.642 \\
(1.306)\end{array}$ & $\begin{array}{c}0.111 \\
(0.045)\end{array}$ & $\begin{array}{c}0.079 \\
(0.029)\end{array}$ \\
\hline 1992 & $\begin{array}{c}34.977 \\
(18.234)\end{array}$ & $\begin{array}{c}41.566 \\
(12.714)\end{array}$ & $\begin{array}{c}5.260 \\
(3.747)\end{array}$ & $\begin{array}{c}5.535 \\
(1.394)\end{array}$ & $\begin{array}{c}0.110 \\
(0.043)\end{array}$ & $\begin{array}{c}0.077 \\
(0.031)\end{array}$ \\
\hline 1993 & $\begin{array}{c}34.047 \\
(17.306)\end{array}$ & $\begin{array}{c}40.689 \\
(12.223)\end{array}$ & $\begin{array}{c}5.108 \\
(3.528) \\
\end{array}$ & $\begin{array}{c}5.535 \\
(1.380)\end{array}$ & $\begin{array}{c}0.108 \\
(0.045)\end{array}$ & $\begin{array}{c}0.075 \\
(0.032)\end{array}$ \\
\hline
\end{tabular}


Table 2 Cont'd: Global Trend in Main Personal Income Tax Variables

\begin{tabular}{|c|c|c|c|c|c|c|}
\hline & \multirow{2}{*}{$\begin{array}{c}\text { Unweighted } \\
\text { Top PIT } \\
\text { Rate } \\
\end{array}$} & \multicolumn{5}{|c|}{ Weighted } \\
\hline & & $\begin{array}{c}\text { Top PIT } \\
\text { Rate }\end{array}$ & $\begin{array}{c}\text { Number of } \\
\text { Brackets }\end{array}$ & Complex & MRP1 & ARP1 \\
\hline 1994 & $\begin{array}{c}33.401 \\
(16.709)\end{array}$ & $\begin{array}{c}42.830 \\
(10.800)\end{array}$ & $\begin{array}{c}5.333 \\
(2.758)\end{array}$ & $\begin{array}{c}5.669 \\
(1.359)\end{array}$ & $\begin{array}{c}0.108 \\
(0.041)\end{array}$ & $\begin{array}{c}0.076 \\
(0.031)\end{array}$ \\
\hline 1995 & $\begin{array}{c}33.024 \\
(16.198)\end{array}$ & $\begin{array}{c}42.786 \\
(10.478)\end{array}$ & $\begin{array}{c}5.554 \\
(2.765)\end{array}$ & $\begin{array}{c}5.563 \\
(1.378)\end{array}$ & $\begin{array}{c}0.094 \\
(0.036)\end{array}$ & $\begin{array}{c}0.066 \\
(0.031)\end{array}$ \\
\hline 1996 & $\begin{array}{c}32.813 \\
(16.257)\end{array}$ & $\begin{array}{c}42.894 \\
(10.331)\end{array}$ & $\begin{array}{c}5.362 \\
(2.715)\end{array}$ & $\begin{array}{c}5.652 \\
(1.375)\end{array}$ & $\begin{array}{c}0.103 \\
(0.037)\end{array}$ & $\begin{array}{c}0.073 \\
(0.031)\end{array}$ \\
\hline 1997 & $\begin{array}{c}32.785 \\
(15.954)\end{array}$ & $\begin{array}{c}42.463 \\
(10.370)\end{array}$ & $\begin{array}{c}5.195 \\
(2.091)\end{array}$ & $\begin{array}{c}5.641 \\
(1.372)\end{array}$ & $\begin{array}{c}0.104 \\
(0.039)\end{array}$ & $\begin{array}{c}0.074 \\
(0.031)\end{array}$ \\
\hline 1998 & $\begin{array}{c}32.657 \\
(15.875)\end{array}$ & $\begin{array}{c}41.972 \\
(10.367)\end{array}$ & $\begin{array}{c}5.052 \\
(1.910)\end{array}$ & $\begin{array}{c}5.621 \\
(1.289)\end{array}$ & $\begin{array}{c}0.104 \\
(0.040)\end{array}$ & $\begin{array}{c}0.073 \\
(0.032)\end{array}$ \\
\hline 1999 & $\begin{array}{c}32.335 \\
(15.627)\end{array}$ & $\begin{array}{c}40.271 \\
(9.589)\end{array}$ & $\begin{array}{c}4.907 \\
(1.876)\end{array}$ & $\begin{array}{c}5.645 \\
(1.285)\end{array}$ & $\begin{array}{c}0.102 \\
(0.039)\end{array}$ & $\begin{array}{c}0.072 \\
(0.032)\end{array}$ \\
\hline 2000 & $\begin{array}{c}31.910 \\
(15.463)\end{array}$ & $\begin{array}{l}39.936 \\
(9.331)\end{array}$ & $\begin{array}{c}4.851 \\
(1.855)\end{array}$ & $\begin{array}{c}5.630 \\
(1.260)\end{array}$ & $\begin{array}{c}0.101 \\
(0.034)\end{array}$ & $\begin{array}{c}0.073 \\
(0.032)\end{array}$ \\
\hline 2001 & $\begin{array}{c}31.224 \\
(15.159)\end{array}$ & $\begin{array}{l}39.346 \\
(9.328)\end{array}$ & $\begin{array}{c}5.049 \\
(1.883)\end{array}$ & $\begin{array}{c}5.508 \\
(1.231)\end{array}$ & $\begin{array}{c}0.098 \\
(0.034)\end{array}$ & $\begin{array}{c}0.069 \\
(0.029)\end{array}$ \\
\hline 2002 & $\begin{array}{c}30.593 \\
(14.772)\end{array}$ & $\begin{array}{l}38.727 \\
(9.225)\end{array}$ & $\begin{array}{c}5.103 \\
(1.864)\end{array}$ & $\begin{array}{c}5.872 \\
(1.417)\end{array}$ & $\begin{array}{c}0.101 \\
(0.036)\end{array}$ & $\begin{array}{c}0.072 \\
(0.032)\end{array}$ \\
\hline 2003 & $\begin{array}{c}29.914 \\
(14.720)\end{array}$ & $\begin{array}{l}37.353 \\
(9.106)\end{array}$ & $\begin{array}{c}5.073 \\
(1.853)\end{array}$ & $\begin{array}{c}5.825 \\
(1.416)\end{array}$ & $\begin{array}{c}0.099 \\
(0.036)\end{array}$ & $\begin{array}{c}0.069 \\
(0.031)\end{array}$ \\
\hline 2004 & $\begin{array}{c}29.825 \\
(14.611)\end{array}$ & $\begin{array}{l}37.062 \\
(9.085)\end{array}$ & $\begin{array}{l}5.050 \\
(1.862)\end{array}$ & $\begin{array}{c}5.800 \\
(1.424)\end{array}$ & $\begin{array}{c}0.100 \\
(0.040)\end{array}$ & $\begin{array}{c}0.066 \\
(0.030)\end{array}$ \\
\hline 2005 & $\begin{array}{c}29.011 \\
(14.492) \\
\end{array}$ & $\begin{array}{c}36.434 \\
(8.815) \\
\end{array}$ & $\begin{array}{c}5.031 \\
(1.869)\end{array}$ & $\begin{array}{c}5.747 \\
(1.477) \\
\end{array}$ & $\begin{array}{c}0.096 \\
(0.035) \\
\end{array}$ & $\begin{array}{c}0.064 \\
(0.029) \\
\end{array}$ \\
\hline $\mathrm{N}$ & 3613 & 3613 & 3143 & 3132 & 3082 & 3082 \\
\hline
\end{tabular}

Notes: Standard deviations are in parentheses. Weight is GDP in constant 1990 U.S. dollars. Complex is complexity index, MRP1 and ARP1 is marginal and average tax rate progressions up to an income level equivalent to four times GDP per capita. All variables are described in the text. 
Table 3: Distribution of Countries by Top PIT Rates

\begin{tabular}{rrrcccc}
\hline Period & $\mathbf{0 \%}$ & $\mathbf{1 - 2 0 \%}$ & $\mathbf{2 1 - 3 0 \%}$ & $\mathbf{3 1 - 4 0 \%}$ & $\mathbf{4 1 - 6 0 \%}$ & $\mathbf{6 1 - 9 5 \%}$ \\
\hline $1981-1985$ & 13.11 & 5.42 & 2.80 & 6.99 & 46.33 & 25.35 \\
$1986-1990$ & 12.87 & 8.47 & 5.70 & 14.66 & 47.07 & 11.24 \\
$1991-1995$ & 11.55 & 10.05 & 14.13 & 32.20 & 29.62 & 2.45 \\
$1996-2000$ & 10.32 & 11.53 & 19.78 & 34.47 & 22.94 & 0.97 \\
$2001-2005$ & 9.69 & 15.80 & 23.30 & 34.03 & 16.26 & 0.92 \\
\hline
\end{tabular}


Table 4: Top Statutory PIT Rates by Period and Country Category

\begin{tabular}{|c|c|c|c|c|c|}
\hline Period & High Income & $\begin{array}{c}\text { Upper Middle } \\
\text { Income }\end{array}$ & $\begin{array}{c}\text { Lower Middle } \\
\text { Income }\end{array}$ & Low Income & Total \\
\hline \multicolumn{6}{|c|}{ Panel A: Weighted Top PIT Rates (Mean and Standard Deviation) } \\
\hline $1981-1985$ & $\begin{array}{c}58.012 \\
(13.588)\end{array}$ & $\begin{array}{c}61.111 \\
(11.506)\end{array}$ & $\begin{array}{c}54.188 \\
(10.833)\end{array}$ & $\begin{array}{c}52.138 \\
(9.961)\end{array}$ & $\begin{array}{c}57.936 \\
(13.205)\end{array}$ \\
\hline $1986-1990$ & $\begin{array}{c}46.494 \\
(15.121)\end{array}$ & $\begin{array}{c}55.764 \\
(14.115)\end{array}$ & $\begin{array}{c}48.736 \\
(11.648)\end{array}$ & $\begin{array}{l}47.085 \\
(6.559)\end{array}$ & $\begin{array}{c}47.848 \\
(14.853)\end{array}$ \\
\hline $1991-1995$ & $\begin{array}{c}42.663 \\
(11.347)\end{array}$ & $\begin{array}{c}37.546 \\
(15.018)\end{array}$ & $\begin{array}{c}42.242 \\
(14.118)\end{array}$ & $\begin{array}{l}43.312 \\
(6.737)\end{array}$ & $\begin{array}{c}42.179 \\
(11.823)\end{array}$ \\
\hline $1996-2000$ & $\begin{array}{c}42.791 \\
(9.500)\end{array}$ & $\begin{array}{c}33.206 \\
(11.768)\end{array}$ & $\begin{array}{c}39.933 \\
(8.731)\end{array}$ & $\begin{array}{l}36.258 \\
(8.582)\end{array}$ & $\begin{array}{c}41.456 \\
(10.037)\end{array}$ \\
\hline $2001-2005$ & $\begin{array}{l}38.908 \\
(8.327)\end{array}$ & $\begin{array}{c}29.546 \\
(11.549)\end{array}$ & $\begin{array}{c}35.818 \\
(10.647)\end{array}$ & $\begin{array}{l}31.823 \\
(7.001)\end{array}$ & $\begin{array}{l}37.739 \\
(9.149)\end{array}$ \\
\hline \multicolumn{6}{|c|}{ Panel B: Trend Coefficient for Top Statutory PIT Rates } \\
\hline $1981-1985$ & $\begin{array}{c}-1.481 * \\
{[189]}\end{array}$ & $\begin{array}{r}1.149 \\
{[99]}\end{array}$ & $\begin{array}{r}-0.367 \\
{[197]}\end{array}$ & $\begin{array}{c}-1.871^{*} \\
{[87]}\end{array}$ & $\begin{array}{c}-1.110 * * \\
{[572]}\end{array}$ \\
\hline $1986-1990$ & $\begin{array}{c}-3.744 * * \\
{[205]}\end{array}$ & $\begin{array}{c}-3.445^{* *} \\
{[108]}\end{array}$ & $\begin{array}{c}-1.340^{*} \\
{[202]}\end{array}$ & $\begin{array}{r}0.238 \\
{[99]}\end{array}$ & $\begin{array}{c}-3.408^{* *} \\
{[614]}\end{array}$ \\
\hline 1991 - 1995 & $\begin{array}{c}0.760 \\
{[209]}\end{array}$ & $\begin{array}{c}-3.313^{* *} \\
{[139]}\end{array}$ & $\begin{array}{c}-3.220^{* *} \\
{[242]}\end{array}$ & $\begin{array}{c}-1.332^{* * *} \\
{[146]}\end{array}$ & $\begin{array}{c}0.099 \\
{[736]}\end{array}$ \\
\hline $1996-2000$ & $\begin{array}{c}-0.870^{*} \\
{[240]}\end{array}$ & $\begin{array}{c}0.241 \\
{[149]}\end{array}$ & $\begin{array}{c}0.302 \\
{[208]}\end{array}$ & $\begin{array}{c}-2.528 * * \\
{[227]}\end{array}$ & $\begin{array}{c}-0.814^{* *} \\
{[824]}\end{array}$ \\
\hline $2001-2005$ & $\begin{array}{c}-0.862 * \\
{[261]}\end{array}$ & $\begin{array}{c}-0.590 \\
{[142]}\end{array}$ & $\begin{array}{c}0.182 \\
{[219]}\end{array}$ & $\begin{array}{c}-0.467 \\
{[245]}\end{array}$ & $\begin{array}{c}-0.745^{* *} \\
{[867]}\end{array}$ \\
\hline All years & $\begin{array}{c}-0.797 * * \\
{[1104]}\end{array}$ & $\begin{array}{c}-1.752 * * \\
{[637]}\end{array}$ & $\begin{array}{c}-0.855^{* *} \\
{[1068]}\end{array}$ & $\begin{array}{c}-1.059 * * \\
{[804]}\end{array}$ & $\begin{array}{c}-0.892^{* *} \\
{[3613]}\end{array}$ \\
\hline
\end{tabular}

Notes: Means and standard deviations (in parentheses) of top PIT rates in Panel A are weighted by GDP in constant 1990 U.S. dollars. Panel B reports the weighted estimates of the slope coefficients from regressing top PIT rates on the trend variable; ** significant at $1 \%$ level, * significant at $5 \%$ level. Number of observations is in brackets, and it is the same in both panels. 
Table 5: Trend Coefficients for Actual PIT Rates by Period and Country Category

\begin{tabular}{llllll}
\hline \multicolumn{1}{c}{ Period } & \multirow{2}{*}{ High Income } & $\begin{array}{c}\text { Upper Middle } \\
\text { Income }\end{array}$ & $\begin{array}{c}\text { Lower Middle } \\
\text { Income }\end{array}$ & $\begin{array}{c}\text { Low } \\
\text { Income }\end{array}$ & Total \\
\hline $\begin{array}{llll}\text { Marginal PIT rate } \\
\text { 1.y }\end{array}$ & & & & \\
$2 \cdot y$ & $-0.491^{* *}$ & $-0.172^{* *}$ & $-0.347^{* *}$ & 0.054 & $-0.491^{* *}$ \\
$3 \cdot y$ & $-0.623^{* *}$ & $-0.309^{* *}$ & $-0.291^{* *}$ & 0.037 & $-0.622^{* *}$ \\
$4 \cdot y$ & $-0.731^{* *}$ & $-0.413^{* *}$ & $-0.378^{* *}$ & $0.335^{* *}$ & $-0.716^{* *}$ \\
\hline Average PIT rate & & $-0.428^{* *}$ & $-0.414^{* *}$ & $0.716^{* *}$ & $-0.756^{* *}$ \\
$1 \cdot y$ & $-0.796^{* *}$ & & & & \\
$2 \cdot y$ & $-0.329^{* *}$ & -0.022 & $-0.255^{* *}$ & 0.037 & $-0.323^{* *}$ \\
$3 \cdot y$ & $-0.431^{* *}$ & $-0.128^{*}$ & $-0.280^{* *}$ & 0.040 & $-0.431^{* *}$ \\
$4 \cdot y$ & $-0.523^{* *}$ & $-0.218^{* *}$ & $-0.296^{* *}$ & 0.068 & $-0.520^{* *}$ \\
\hline
\end{tabular}

Notes: ** Significant at $1 \%$ level. * Significant at $5 \%$ level. Reported are the estimated slopes from regressing marginal and average PIT rates on the trend variable, $y$ is a country's GDP per capita. 
Table 6: Complexity Index Scores

\begin{tabular}{lcccc}
\hline \multicolumn{1}{c}{ Factor } & $\mathbf{0}$ & $\mathbf{1}$ & $\mathbf{2}$ & $\mathbf{3}$ \\
\hline Allowances/ tax credits & None exists & Standard & Non standard & - \\
Tax schedules & One & Multiple & - & - \\
Tax formula & Standard & Non standard & - & - \\
Local taxes & None exists & Low & High & - \\
Surtax & None exists & Exists & - & - \\
Number of tax brackets & None exists & $1-2$ & $3-5$ & $>6$ \\
\hline
\end{tabular}


Table 7: Complexity Components of PIT Systems by Period

\begin{tabular}{|c|c|c|c|c|c|c|c|c|}
\hline \multirow[b]{2}{*}{ Period } & \multicolumn{2}{|c|}{ Allowances/credits } & \multirow[b]{2}{*}{ Surtax } & \multicolumn{2}{|c|}{ Local Taxes } & \multirow{2}{*}{$\begin{array}{l}\text { Multiple } \\
\text { Schedule }\end{array}$} & \multirow{2}{*}{$\begin{array}{c}\text { Tax } \\
\text { Formula }\end{array}$} & \multirow{2}{*}{$\begin{array}{l}\text { Complexity } \\
\text { Index }\end{array}$} \\
\hline & Standard & $\begin{array}{c}\text { Non - } \\
\text { Standard } \\
\end{array}$ & & Low & High & & & \\
\hline $1981-1985$ & $\begin{array}{c}0.275 \\
(0.447)\end{array}$ & $\begin{array}{c}0.527 \\
(0.500)\end{array}$ & $\begin{array}{c}0.281 \\
(0.450)\end{array}$ & $\begin{array}{c}0.067 \\
(0.250)\end{array}$ & $\begin{array}{c}0.093 \\
(0.290)\end{array}$ & $\begin{array}{c}0.207 \\
(0.406)\end{array}$ & $\begin{array}{c}0.193 \\
(0.395)\end{array}$ & $\begin{array}{c}4.666 \\
(2.373)\end{array}$ \\
\hline $1986-1990$ & $\begin{array}{c}0.289 \\
(0.453)\end{array}$ & $\begin{array}{c}0.482 \\
(0.500)\end{array}$ & $\begin{array}{c}0.297 \\
(0.457)\end{array}$ & $\begin{array}{c}0.081 \\
(0.272)\end{array}$ & $\begin{array}{c}0.092 \\
(0.290)\end{array}$ & $\begin{array}{c}0.228 \\
(0.420)\end{array}$ & $\begin{array}{c}0.182 \\
(0.387)\end{array}$ & $\begin{array}{c}4.479 \\
(2.344)\end{array}$ \\
\hline $1991-1995$ & $\begin{array}{c}0.307 \\
(0.461)\end{array}$ & $\begin{array}{c}0.413 \\
(0.493)\end{array}$ & $\begin{array}{c}0.266 \\
(0.442)\end{array}$ & $\begin{array}{c}0.087 \\
(0.282)\end{array}$ & $\begin{array}{c}0.080 \\
(0.271)\end{array}$ & $\begin{array}{c}0.198 \\
(0.399)\end{array}$ & $\begin{array}{c}0.125 \\
(0.331)\end{array}$ & $\begin{array}{c}4.025 \\
(2.167)\end{array}$ \\
\hline $1996-2000$ & $\begin{array}{c}0.315 \\
(0.465)\end{array}$ & $\begin{array}{c}0.404 \\
(0.491)\end{array}$ & $\begin{array}{c}0.230 \\
(0.421)\end{array}$ & $\begin{array}{c}0.108 \\
(0.311)\end{array}$ & $\begin{array}{c}0.067 \\
(0.250)\end{array}$ & $\begin{array}{c}0.192 \\
(0.394)\end{array}$ & $\begin{array}{c}0.107 \\
(0.309)\end{array}$ & $\begin{array}{c}3.941 \\
(2.040)\end{array}$ \\
\hline $2001-2005$ & $\begin{array}{c}0.307 \\
(0.462)\end{array}$ & $\begin{array}{c}0.397 \\
(0.490)\end{array}$ & $\begin{array}{c}0.212 \\
(0.409)\end{array}$ & $\begin{array}{c}0.102 \\
(0.302)\end{array}$ & $\begin{array}{c}0.069 \\
(0.253)\end{array}$ & $\begin{array}{c}0.172 \\
(0.378)\end{array}$ & $\begin{array}{c}0.092 \\
(0.289)\end{array}$ & $\begin{array}{c}3.788 \\
(1.964)\end{array}$ \\
\hline $\mathrm{N}$ & 3388 & 3388 & 3395 & 3392 & 3392 & 3387 & 3143 & 3132 \\
\hline
\end{tabular}

Notes: Standard deviations are in parentheses. Reported are unconditional means. Omitted categories are countries with no basic allowances or tax credits and no local taxes. 
Table 8: Distribution of Countries by the Number of Brackets, \%

\begin{tabular}{rrrrrrr}
\hline Period & $\mathbf{0}$ & $\mathbf{1 - 3}$ & $\mathbf{4 - 5}$ & $\mathbf{6 - 9}$ & $\mathbf{1 0 - 1 9}$ & $\mathbf{2 0 +}$ \\
\hline $1981-1985$ & 15.76 & 6.30 & 2.73 & 25.00 & 41.18 & 9.03 \\
$1986-1990$ & 14.71 & 12.10 & 11.92 & 25.70 & 30.17 & 5.40 \\
$1991-1995$ & 13.30 & 19.41 & 26.60 & 26.29 & 12.68 & 1.72 \\
$1996-2000$ & 11.50 & 21.65 & 28.28 & 28.01 & 9.74 & 0.81 \\
$2001-2005$ & 11.17 & 23.54 & 31.78 & 27.93 & 5.19 & 0.40 \\
\hline
\end{tabular}


Table 9: Structural Progressivity Measures of PIT Systems by Period

\begin{tabular}{|c|c|c|c|c|c|}
\hline \multirow[t]{2}{*}{ Period } & \multicolumn{2}{|c|}{$\begin{array}{c}\text { Marginal Rate } \\
\text { Progression }\end{array}$} & \multicolumn{2}{|c|}{$\begin{array}{c}\text { Average Rate } \\
\text { Progression }\end{array}$} & \multirow[t]{2}{*}{$\mathbf{N}$} \\
\hline & MRP1 & MRP2 & ARP1 & ARP2 & \\
\hline \multicolumn{6}{|c|}{ Panel A: Weighted Progressivity Measures } \\
\hline $1981-1985$ & $\begin{array}{c}0.141 \\
(0.049)\end{array}$ & $\begin{array}{c}0.170 \\
(0.077)\end{array}$ & $\begin{array}{c}0.102 \\
(0.038)\end{array}$ & $\begin{array}{c}0.132 \\
(0.048)\end{array}$ & 459 \\
\hline 1986 - 1990 & $\begin{array}{c}0.120 \\
(0.045)\end{array}$ & $\begin{array}{c}0.136 \\
(0.077)\end{array}$ & $\begin{array}{c}0.088 \\
(0.033)\end{array}$ & $\begin{array}{c}0.115 \\
(0.043)\end{array}$ & 517 \\
\hline $1991-1995$ & $\begin{array}{c}0.106 \\
(0.042)\end{array}$ & $\begin{array}{c}0.134 \\
(0.076)\end{array}$ & $\begin{array}{c}0.075 \\
(0.031)\end{array}$ & $\begin{array}{c}0.098 \\
(0.041)\end{array}$ & 624 \\
\hline $1996-2000$ & $\begin{array}{c}0.103 \\
(0.038)\end{array}$ & $\begin{array}{c}0.115 \\
(0.055)\end{array}$ & $\begin{array}{c}0.073 \\
(0.032)\end{array}$ & $\begin{array}{c}0.098 \\
(0.040)\end{array}$ & 734 \\
\hline $2001-2005$ & $\begin{array}{c}0.099 \\
(0.036)\end{array}$ & $\begin{array}{c}0.114 \\
(0.060)\end{array}$ & $\begin{array}{c}0.068 \\
(0.030)\end{array}$ & $\begin{array}{c}0.095 \\
(0.040)\end{array}$ & 748 \\
\hline \multicolumn{6}{|c|}{ Panel B: Trend Coefficient for Progressivity Measures } \\
\hline All countries & $-0.002 * *$ & $-0.002 * *$ & $-0.002 * *$ & $-0.002 * *$ & 3082 \\
\hline High income & $-0.002 * *$ & $-0.003 * *$ & $-0.002 * *$ & $-0.002 * *$ & 1035 \\
\hline Upper middle income & $-0.002 * *$ & $-0.003 * *$ & $-0.001 * *$ & $-0.002 * *$ & 571 \\
\hline Lower middle income & $-0.001^{* *}$ & -0.000 & $-0.001 * *$ & -0.000 & 827 \\
\hline Low income & $0.002 * *$ & $0.001 * *$ & $0.000 * *$ & 0.000 & 649 \\
\hline
\end{tabular}

Notes: MRP1 and ARP1 is marginal and average tax rate progressions up to an income level equivalent to four times $y$, where $y$ is a country's GDP per capita; MRP2 and ARP2 is marginal and average tax rate progressions for the levels of income between $y$ and 3.y. Means and standard deviations (in parentheses) of progressivity measures in Panel A are weighted by GDP in constant 1990 U.S. dollars. Panel B reports the weighted estimates of the slope coefficients from regressing progressivity measures on the trend variable; ** significant at $1 \%$ level, * significant at $5 \%$ level. 


\section{Figure 1: Top Statutory PIT Rate by Income Group, 1981-2005}
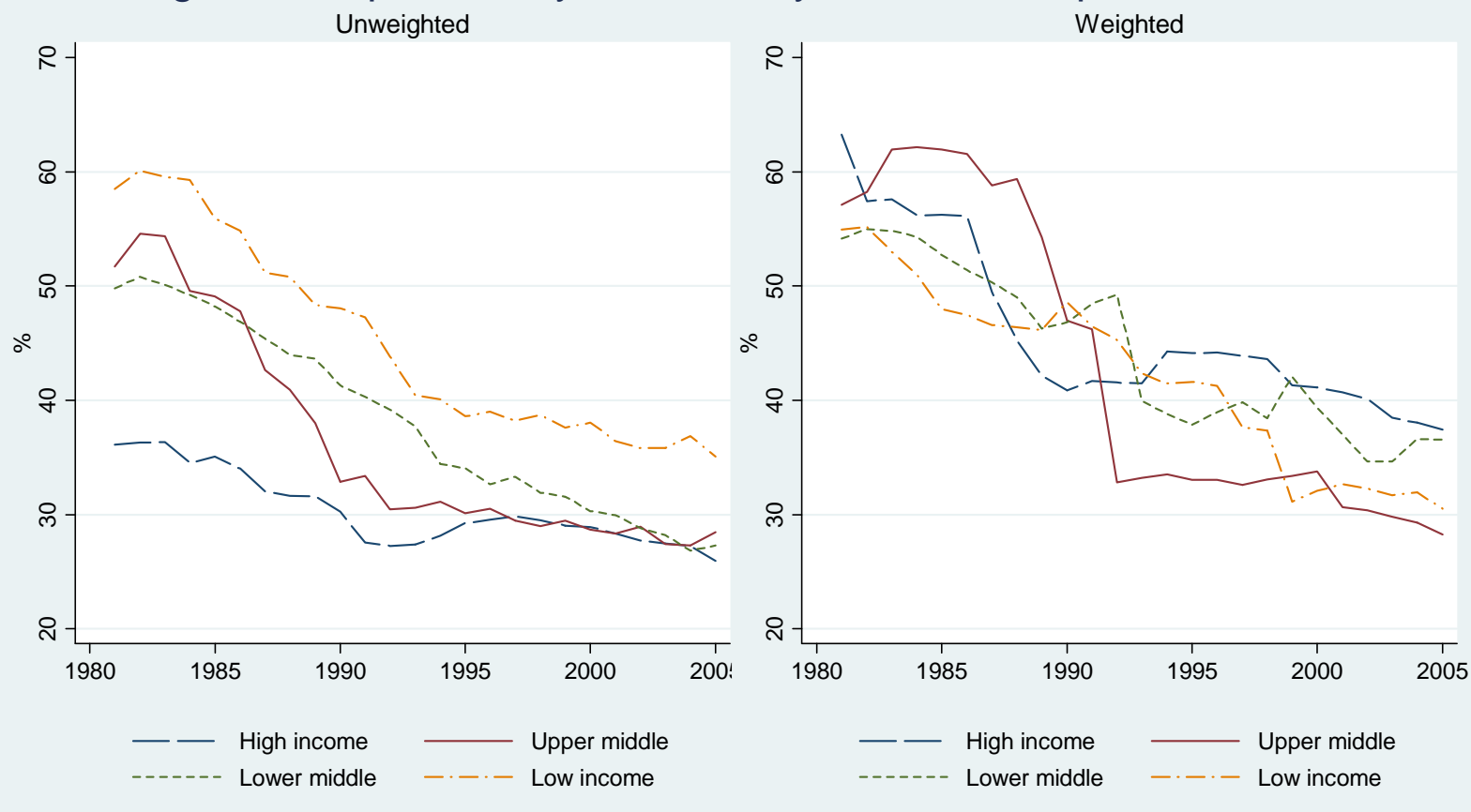
Figure 2: Actual PIT Rates, 1981-2005
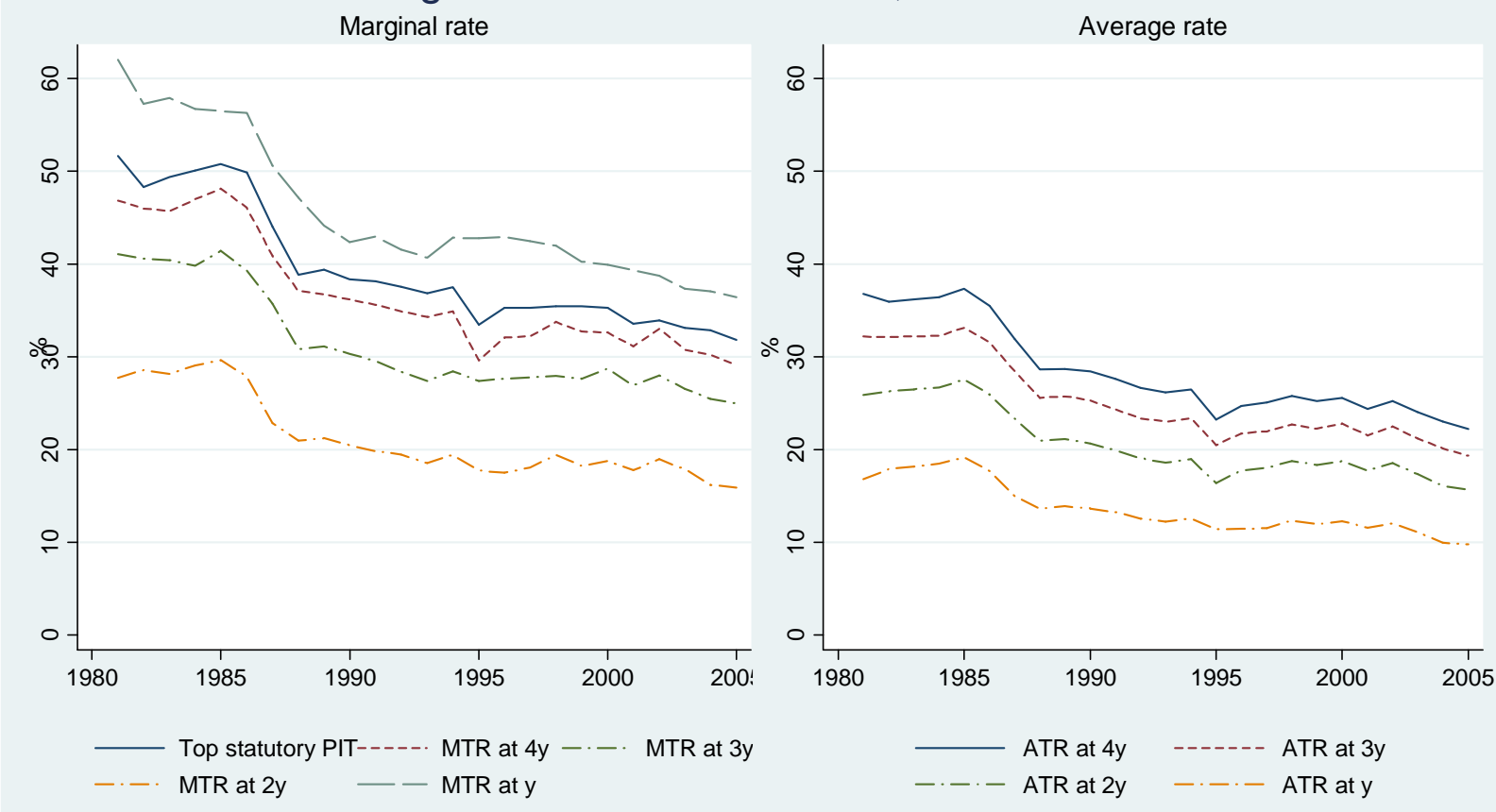

Notes: Both marginal and average rates are weighted by GDP in constant 1990 U.S. dollars; $y$ denotes the level of gross income equivalent to a country's GDP per capita. 
Figure 3: PIT Complexity by Income Group, 1981-2005
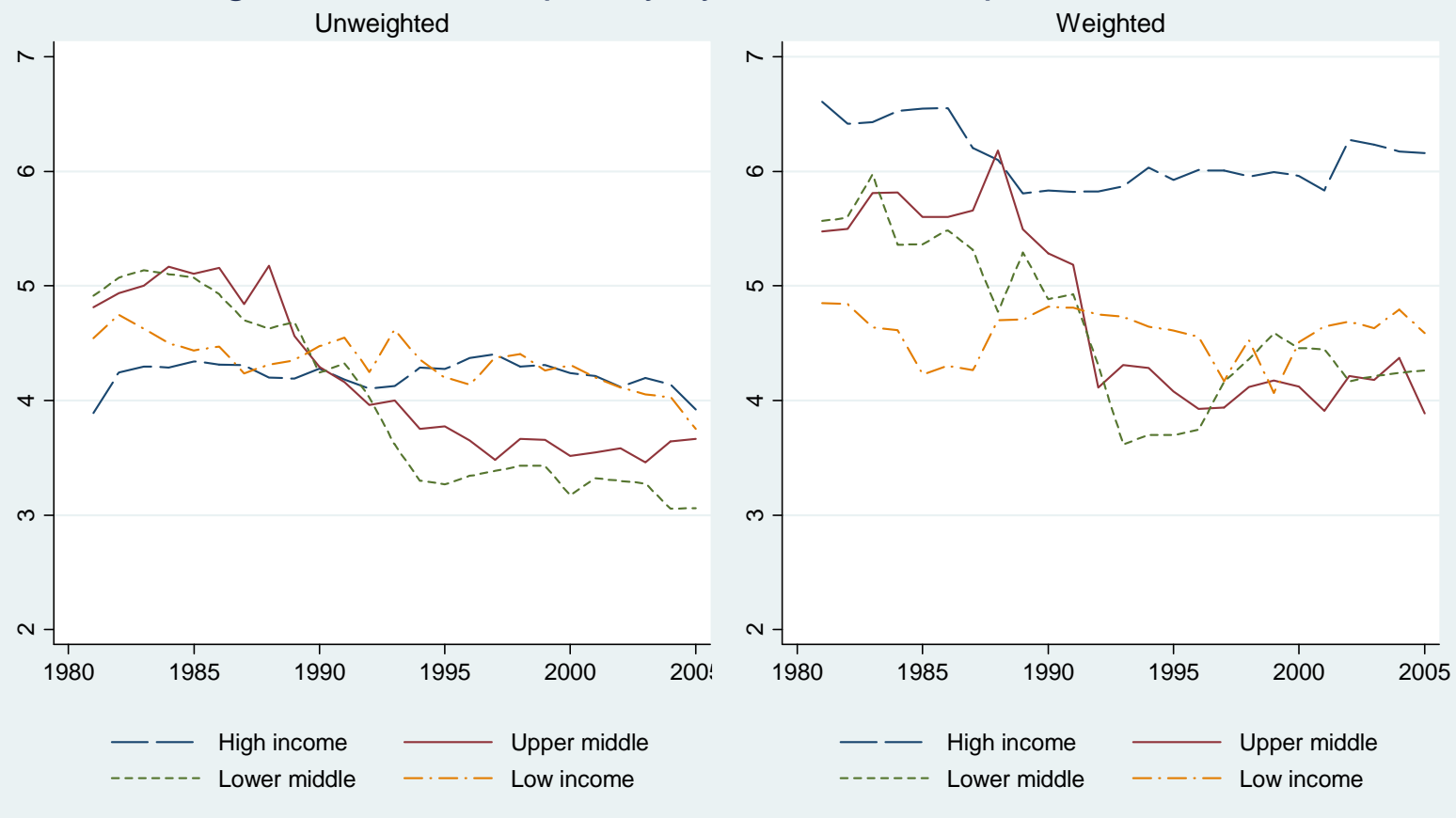
Figure 4: Number of Brackets by Income Group, 1981-2005
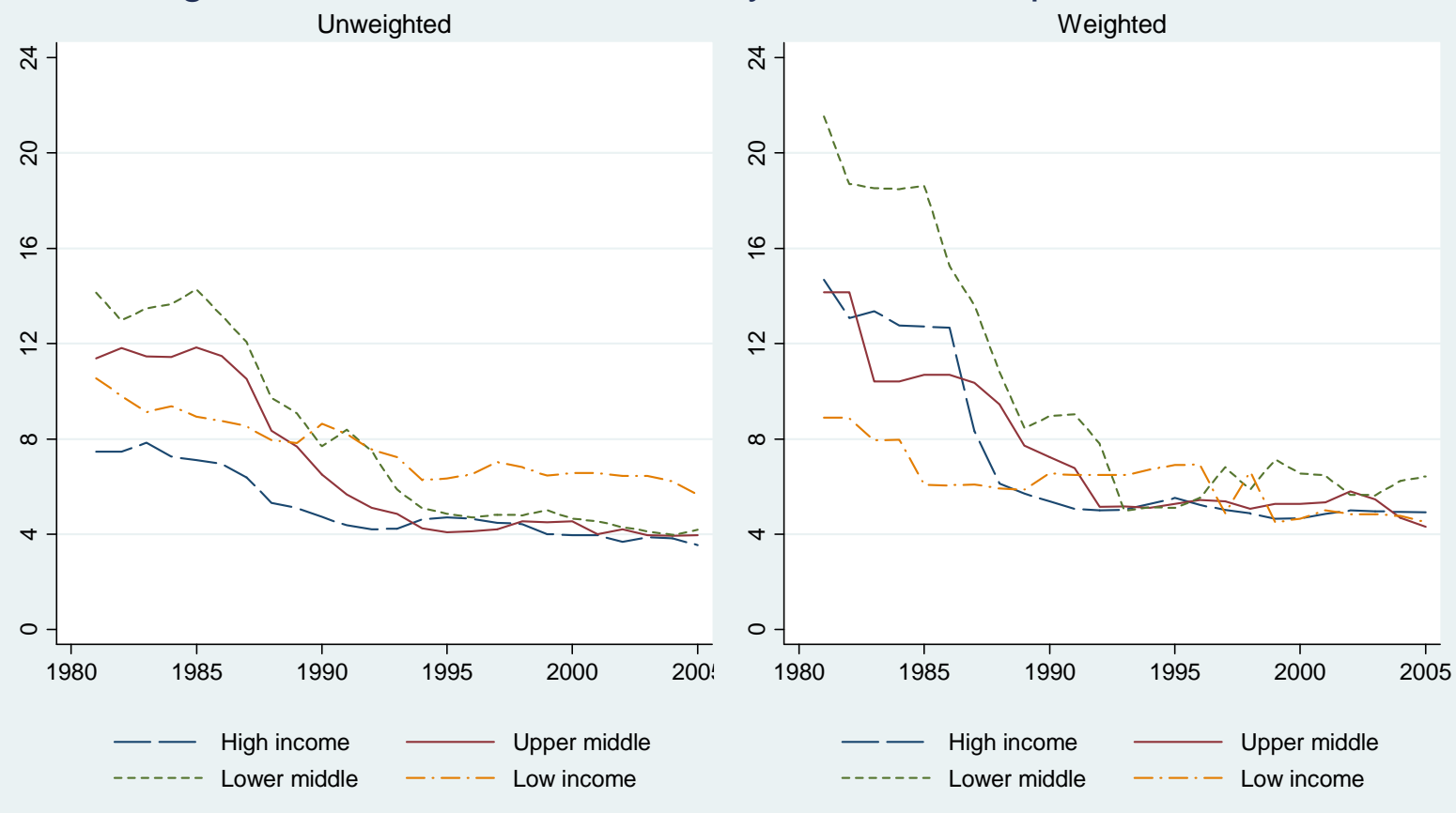


\section{Appendix 1: Notes on Data Sources}

The personal income tax dataset was built using raw data that was assembled from more than 100 distinct reference books and data sets. Of these, perhaps the most important source for PIT data are the tax anthologies published at international accounting firms such as Deloitte, Haskins and Sells, Coopers and Lybrand, and PricewaterhouseCoopers. These publications offer comprehensive coverage of PIT structure for 90-120 countries beginning in 1981 and provided the preponderance of our data.

An equally essential reference for acquiring data was found in international organization publications. There are several references here that deserve attention. One specialized publication, the International Bureau of Fiscal Documentation's European Tax Handbook series, offers comprehensive in depth coverage of European national tax systems beginning in 1990. Another specialized source is the OECD's Tax Benefit Position of Employees and their numerous online personal income tax data sets that reports income tax data going back to the 1970's for OECD countries. Helpful PIT data on developing countries was found at the World Bank, European Bank of Reconstruction and Development, and the International Monetary Fund. With these references, we were able to achieve a broader coverage of poorer developing countries as well as to fill in missing data on the high and middle income countries.

In addition to tax anthologies and international organization publications, public policy centers served as a ready reference for both developed and developing country tax data. The most important of these are the University of Michigan's World Tax Data Base, a source that publishes online tax data as far back as 1975, and the Economist Intelligence Unit, whose online tax database covers approximately sixty to seventy countries beginning in 1995. Other policy center data sets that were regularly consulted are the Heritage Foundation, the Fraser institute, and the Brookings Institute's Tax Policy Center. These resources filled a more limited role in the research process, either serving as a starting point in our data collection or more frequently to confirm other data that had already been collected from other sources. Overall, these online datasets tended to have more errors than the other two sorts of references.

Not surprisingly, acquiring clean and consistent panel data from multiple references can be a difficult task as one is required to reconcile contradictory information reported in various sources. This problem is especially true in our case given the scope of the dataset; 25 years with over 145 countries per year. In this connection there are three broad categories of data errors that we had to pay particular attention to: definitional errors, country-specific errors, and editorial omissions and errors.

Definitional errors are referring to cases where different numbers are quoted for the same variable because of differences in definition or reporting style. A common example of this type of errors is where the top statutory rate is quoted inclusive of a national surtax in one source, while another source excludes the national surtax and accounts for the local tax. Still yet another quote will aggregate all three taxes. Although all three definitions are correct, they can cause inconsistency in the series. In this case the reported numbers must be broken down into their component parts to identify the value of interest in order to create consistent series.

Country specific errors generally arise due to differences between income year and assessment year and due to the use of different fiscal calendars, which sometimes do not coincide with the Gregorian calendar. The problem is further compounded if the edition of the particular reference does not distinguish among the various years. Where these differences exist, we use the tax rate in effect on January 1 as the tax rate for the year. Another country specific cause for errors is the use of multiple tax schedules. There are a number of cases where the tax schedule varies 
across employment status, type of employment, sector or residential status. As a general rule, we use the tax schedule applicable to a single individual resident earning wage income in a country's dominant sector.

The last source of inconsistency is based on editorial errors, editorial practices, and decisions that are publication specific. In addition to outright reporting errors, this category encompasses a broad variety of other troublesome issues such as tardy updating, missing data, breaks in publication series, and changing presentation formats. Examples of missing data include abbreviated tax brackets, missing tax rates, unreported or partially reported deductions and tax credits and unreported tax changes. The incidence of publication specific errors and random editorial changes left crucial breaks in the data that had to be filled in by other reputable sources.

Despite the myriad problems working with multiple tax references there were workable solutions to these predicaments. Usually these solutions required tedious calculations or detailed comparison of two or more data sources to confirm a particular number or fact. In some obvious cases, a reasonable assumption could be made about the data in question. Usually, however, the solution to these problems required learning the fundamental details of one tax system or another. Not surprisingly, finishing the data ultimately required some familiarity with over one hundred and fifty individual tax systems going back to 1981.

That said, through careful cleaning of the data we have assembled a valuable consolidated personal income tax resource for scholars doing empirical research.

\section{References on Data Sources}

Blanchard, Olivier Jean, Froot, Kenneth A., and Sachs, Jeffrey D. (1994). The Transition in Eastern Europe, Volume II: Restructuring. Chicago, University of Chicago Press.

Brookings Institute Tax Policy Center, www.taxpolicycenter.org.

Burba, Andrez (1999). “Emerging Leader of the Tax Avant-Garde: Poland's Proposal to Institute a Flat Tax on Individual and Corporate Incomes," Vanderbilt Journal of Transnational Law 32 (5): 1402-1442.

Coopers and Lybrand (1981-1998). International Tax Summaries. New York, John Wiley and Sons, various years.

Deloitte, Haskins and Sells (1983). Deloitte, Haskins and Sells International Tax and Business Guide 1983. New York, Deloitte, Haskins and Sells.

Deloitte, Haskins, and Sells (1985). Deloitte, Haskins and Sells International Tax and Business Guide 1985. New York, Deloitte, Haskins and Sells.

Diamond, Walter H. (2006), Foreign Tax and Trade Briefs. Newark, LexisNexis Mathew Bender and Company, Inc.

Economist Intelligence Unit (1995-2007). EIU Country Reports, www.eiu.com.

European Bank for Reconstruction and Development (1994-2006). Transition Reports. London: European Bank for Reconstruction and Development, various years. 
Fraser Institute (1995-2006). Economic Freedom of the World, www. freetheworld.com/2006/2006Dataset.xls (downloaded in January 2007).

Grey, Cheryl (1990). "Tax Systems in the Reforming Socialist Economies of Europe,” World Bank Working Paper, No. s501, Washington D.C., World Bank.

Hassan, Fareed M.A. (1998). "Revenue Productive Income Tax Structures and Tax Reforms in Emerging Market Economies: Evidence from Bulgaria,” IMF Working Paper, No. 1927, Washington D.C., International Monetary Fund.

Heritage Foundation (2006). Index of Economic Freedom, www.heritage.org/index/countries.cfm

Horvath, Balazs and Szekely, Istvan (2001) "The Role of Medium Term Fiscal Frameworks: The Case of Bulgaria,” IMF Working Paper 01/11, Washington D.C., International Monetary Fund.

International Bureau of Fiscal Documentation (1990-2006). European Tax Handbook. Amsterdam: International Bureau of Fiscal Documentation, various years.

International Monetary Fund (1998-2007). IMF Country Reports, various country reports, www.imf.org/external/pubind.htm.

International Monetary Fund (1982-2007). IMF Occasional Papers, various papers, Washington D.C., International Monetary Fund.

Lorie, Henry (2003). "Priorities for Further Fiscal Reforms in the Commonwealth of Independent States,” IMF Working Paper 03/209, Washington D.C., International Monetary Fund.

Mitchell, Daniel (2007). "Iceland Joins the Flat Tax Club,” Cato Institute Tax and Budget Bulletin, No. 43, Washington, D.C., Cato Institute.

Morisson, Christian and Talbi, Bechi (1996). Long Term Growth in Tunisia. Paris: Development Center of the Organization for Economic Development.

Nexia International (1992). International Handbook of Corporate and Personal Taxes. New York: Chapman and Hall.

Nexia International (1994). International Handbook of Corporate and Personal Taxes. New York: Chapman and Hall.

OECD (1981, 1984). Economic Survey: Turkey. OECD, Paris.

OECD (1979-1995). Tax and Benefits of Productive Workers, various issues. Paris: OECD.

OECD (1996-1998). Tax Benefit Position of Employees, various issues. Paris: OECD.

OECD (1999-2005). Taxing Wages, various issues. Paris: OECD. 
OECD (1990). Economic Survey: Iceland. Paris: OECD.

OECD (1991). Economic Survey: Hungary. Paris: OECD.

OECD (1997). Economic Survey: Bulgaria 1996-1997. Paris: OECD.

Price Waterhouse (1981-1998). Individual Taxes: A Worldwide Summary, various years. New York: John Wiley and Sons.

PriceWaterhouseCoopers (1999-2005). Individual Taxes: A Worldwide Summary, various years. New York: John Wiley and Sons.

Sicat, Gerardo P. and Virmani, Arvind (1988). "Personal Income Taxes in Developing Countries," World Bank Economic Review 2(1): 123-138.

Stepanyan, Vahram (2003). "Reforming Tax Systems: Experience of the Baltics, Russia, and Other Countries of the Former Soviet Union,” IMF Working Paper 03/173, Washington D.C., International Monetary Fund.

Stotsky, Janet and Asegedech Wolde Mariam (2002). "Central American Tax Reform: Trends and Possibilities,” IMF Working Paper 02/227, Washington D.C., International Monetary Fund.

U. S. Department of Commerce International Trade Administration (1980-1990). U.S. Department of Commerce International Marketing Information Series: Overseas Business Reports, various reports, Washington D.C., Government Printing Office.

University of Michigan Office of Tax Policy Research, World Tax Data Base, www.bus.umich.edu/OTPR/otpr/default.asp (downloaded in January 2007).

World Bank, World Development Indicators, www.worldbank.org/data/. 